\title{
STRATEGI PEMASARAN KATALOG PRODUK (STUDI KASUS PENGRAJIN BAMBU SUKODONO SRAGEN)
}

\author{
Aflit Nuryulia Praswati ${ }^{1}$, Syamsudin $^{2}$, Muzakar Isa ${ }^{3}$, Tulus Prijanto ${ }^{4}$ \\ Fakultas Ekonomi dan Bisnis, Universitas Muhammadiyah Surakarta

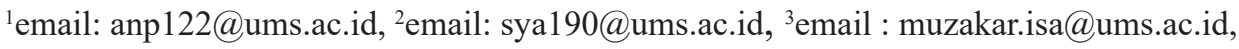 \\ ${ }^{4}$ email: anp122@ums.ac.id
}

\begin{abstract}
The promising prospect of bamboo industry is now evolving not only become handicrafts and small enterprises. Stakeholders of bamboo industry need to pay attention on the potency of this industry for its eco-friendliness, expediencies, and advantages. The bamboo industry in Sragen Regency for instance, develops properly but still faces marketing problems as its primary obstacle. Bamboo craftsmen are commonly supplying products based on customer orders. This study identifies the use of catalogue media to promote bamboo product in Sragen Regency. Using study case for descriptive qualitative, this research clarifies that bamboo craftsmen in Sragen Regency need support for development process. The catalogue arrangement process is started from identification of existing products, containing product name, size, usage, and price. Information of producer profile such as name, address, and telephone are equally important attributes for the catalogue. All information in the catalogue must represent profile and accessibility of the related product in order to attract consumers, and practically for its ease of marketing process. These long process, and bamboo handicraftsmen commitment in promotion obstruct this study to determine the efficency of the catalogue in raising bamboo market.
\end{abstract}

Keywords: Bamboo craftsmen, marketing, catalogue

\begin{abstract}
Abstrak: Prospek industri bambu sangat menjanjikan, pemanfaatannya tidak lagi terbatas pada kerajinan tangan dan industri kecil. Produk kerajinan bambu ramah lingkungan, multi-fungsi, dan menguntungkan, memiliki potensi yang sangat besar apabila diperhatikan secara serius oleh seluruh pemangku kepentingan industri bambu. Industri kerajinan bambu di Kabupaten Sragen saat ini sedang dalam masa pertumbuhan dan masih dihadapkan pada permasalahan utama yaitu proses pemasaran produk. Selama ini para pengrajin hanya memproduksi kerajinan sesuai pesanan yang datang. Penelitian ini bertujuan untuk mengidentifikasi penggunaan media promosi katalog pada kerajinan bambu di Kabupaten Sragen. Metode penelitian ini menggunakan kualitatif deskriptif dengan studi kasus. Hasil dari penelitian menyatakan bahwa para pengrajin masih membutuhkan dukungan dari semua pihak untuk dapat mengembangkan usahanya. Penyusunan katalog dimulai dari mengidentifikasi produk yang sudah dihasilkan. Informasi mengenai produk seperti nama, ukuran, kegunaan dan harga. Informasi mengenai produsen juga sangat penting, seperti nama produsen, alamat, dan contact person. Semua informasi yang ada dikatalog sebagai wakil dari produsen sehingga dapat memudahkan penjualan serta dapat menarik calon pelanggan baru. Keterbatasan dari penelitian ini adalah hasil penerapan katalog sebagai media promosi kerajinan bambu belum bisa dilihat, karena membutuhkan waktu yang cukup lama, serta komitmen dari pengrajin untuk aktif menawarkan produk melalui katalog yang sudah disusun.
\end{abstract}

Kata Kunci: Kerajinan bambu, Pemasaran, Katalog

\section{PENDAHULUAN}

Bambu merupakan tanaman yang memiliki banyak banyak keunggulan baik yaitu waktu tanam yang cepat sehingga bisa menjadi sumber penghasilan masyarakat pedesaan, sebagai solusi dari ancaman polusi udara, dan memperbaiki kondisi air tanah. Tanaman ini cocok untuk memperbaiki kondisi alam khususnya lahan kritis, tanah miring dan rawan longsor. Tanaman bambu yang dibudidayakan dengan baik dapat memberikan nilai tambah ekonomis, dapat berupa bahan bangunan maupun kerajinan. Bambu termasuk tanaman Bamboidae anggota subfamilia rumput, terdapat $1250-1500$ jenis bambu yang ada di dunia, di Indonesia hanya terdapat 10\% sekitar 154 jenis bambu (Wijaya et al, 2004). 
Kabupaten Sragen sebagai salah satu daerah penghasil kerajinan bambu, tepatnya terletak di desa bendo Kecamatan Sukodono Kabupaten Sragen. Di daerah tersebut banyak terdapat tanaman bambu. Jenis bambu yang dapat dibuat sebagai bahan baku kerajinan yaitu bambu pethung, bambu hitam, dan bambu putih yang memiliki kualitas bagus. Ketersediaanbahan bakuinimerupakan potensi yang harus dimanfaatkan dengan baik untuk membuat kerajinan bambu sehingga dapat meningkatkan kondisi ekonomi masyarakat sekitar. Fredicksson, Wadstrom, Medbo (2014) menyatakan bahwa ketersediaan bahan baku berperan penting pada kelancaran proses produksi.

Kerajinan bambu selain membutuhkan tanaman bambu sebagai bahan utama, namun perlu bahan baku penunjang lain seperti sabut kelapa, rotan, kayu, tempurung kelapa, dan bahan pembantu lainnya seperti pelapis anti hama dan jamur. Untuk memenuhi stok bahan baku selain mengambil dari Desa Bendo, para pengrajin juga mengambil bambu dari temanggung karena jenis bambu dari temanggung tidak kalah kualitasnya. Untuk menjaga kualitas bahan baku biasanya bambu dilapisi anti rayap dan anti jamur terutama untuk jenis bambu pethung sehingga kualitas produk bambu ini bisa memiliki umur manfaat mencapai lima hingga delapan tahun. Produk kerajinan yang dihasilkan berupa mebel dan gazebo, produk kerajinan yang lain berupa tudung saji, tirai, souvenir dan pernak pernik, seperti kap lampu, gelas, dan tutup gelas dengan dikombinasikan dengan tempurung kelapa dan bahan lain.

Prospek industri bambu sangat menjanjikan, pemanfaatannya tidak lagi terbatas pada kerajinan tangan dan industri kecil, melainkan meluas sampai perabot rumah tangga lainnya yang digunakan oleh hotel mewah. Modifikasi desain dan bahan baku akan memberikan nilai lebih suatu produk serta keunggulan kompetitif pada kerajinan bambu. Fang-Wu Tung (2012) menyatakan hal serupa, yaitu kerajinan tangan yang dikemas secara kreatif dengan desain inovatif akan lebih komersil.

Potensi bambu sebagai produk kerajinan ramah lingkungan, multi-fungsi, dan menguntungkan, sangatlah besar apabila diperhatikan secara serius oleh seluruh pemangku kepentingan industri bambu. Berdasarkan keterangan pengusaha dan investor bambu, antara lain Oprins $\mathrm{NV}$ dan Fiberstrength USA, nilai bisnis bambu di dunia saat ini mencapai US\$ 7 miliar dan permintaannya dari waktu ke waktu terus meningkat.

PemerintahKabupatenSragensaatinitelah berupaya untuk meningkatkan kesejahteraan masyarakat dengan mendorong terbentuknya sentra-sentra industri di wilayahnya. Hal ini sesuai dengan RPJMD Kabupaten Sragen 2011-2016 yaitu program pengembangan Koperasi dan Usaha Mikro Kecil Menengah Kabupaten Sragen. Pemerintah Kabupaten Sragen melalui Badan Diklat dan Litbang mengupayakan peningkatan kemampuan ketrampilan dengan memberikan pelatihan dan pemagangan bagi para pelaku usaha maupun calon usahawan. Program lanjutan Balitbang Sragen bekerja sama dengan FEB Universitas Muhammadiyah Surakarta untuk melakukan pendampingan bagi pengrajin bambu.

Ada sekitar 16 pengrajin yang aktif dalam pembuatan kerajinan bambu di Desa bendo. Industri kerajinan bambu ini sedang dalam masa awal pertumbuhan dan masih dihadapkan pada berbagai permasalahan. Permasalahan utama yaitu proses pemasaran produk.

Selama ini para pengrajin hanya memproduksi kerajinan sesuai pesanan yang datang. Calon pelanggan datang melihat produk yang ada dan langsung membeli, kurang adanya pilihan jenis produk karena setiap produksi langsung terjual, tidak ada dokumentasi jenis produk, dan belum ada katalog yang menarik. Selama ini para pengrajin memasarkan produknya melalui word of mouth dan mengikuti pameran yang di fasilitasi oleh Pemerintah Daerah Kabupaten Sragen. Produk yang dihasilkan para pengrajin bambu biasanya hanya di letakan dan di pajang di showroom di Desa Bendo atau dijual langsung ke masyarakat sekitar. Katalog yang baik sebaiknya dilengkapi dengan foto produk, kriteria produk (ukuran, harga, lama pemesanan, nama produk, alamat tempat produksi dan pemesanan dll.).

Frances (1998) media promosi katalog sudah digunakan sebagai alat pemasaran sejak 1997. Para produsen melakukan pemasaran secara langsung "door to door". Katalog 
sebagai penggambaran mengenai perusahaan dan produk-produk yang ditawarkan dirancang sedemikian rupa, dari penggunaan kertas, warna, tata letak perlu difikirkan dengan baik.

Untuk meningkatkan penjualan, produsen perlu aktif dalam melakukan direct marketing. Pada pengrajin Bambu direct marketing dimulai dengan menggunakan katalog sebagai media promosi. Katalog disusun secara rinci dan menarik, sehingga dapat menarik calon pelanggan baru. Penelitian ini bertujuan untuk mengidentifikasi penggunaan media promosi katalog pada kerajinan bambu di Kabupaten Sragen.

\section{LANDASAN PUSTAKA}

Pemasaran menurut Kotler dan Keller (2009) menjelaskan bahwa pemasaran adalah mengidentifikasikan dan memenuhi kebutuhan manusia dan sosial. Untuk dapat memenuhi kebutuhan maka muncullah proses menciptakan, menawarkan, dan menukarkan produk yang memiliki komoditas. Strategi pemasaran menurut Tjiptono (2004) adalah alat fundamental yang direncanakan untuk mencapai tujuan perusahaan dengan mengembangkan keunggulan bersaing yang berkesinambungan melalui pasar yang dimasukinya dan program pemasaran yang digunakan untuk melayani pasar sasaran tersebut.

Pemasaran langsung menurut Direct Marketing Association adalah sistem pemasaran interaktif yang menggunakan satu atau lebih media iklan untuk menghasilkan tanggapan dan transaksi yang dapat diukur pada suatu lokasi. Di dalam pemasaran langsung biasanya menggunakan saluran saluran langsung ke konsumen (Consumer direct) untuk menjangkau dan menyerahkan barang dan jasa kepada pelanggan tanpa menggunakan perantara pemasaran. Saluran saluran ini mencakup surat langsung, catalog, telemarketing, tv interaktif, situs internet, dan lain-lain. Para pemasar melakukan pemasaran langsung untuk meningkatkan produktivitas satuan penjualan.

Bambu dapat dijadikan berbagai kerajinan yang bernilai estetis dan ekonomi tinggi. Bambu sudah digunakan untuk memenuhi kebutuhan masyarakat sejak jamam dulu, misal alat jemuran, tikar dan anyaman. Bahkan sekarang bambu dapat dibuat dengan tampilan yang lebih menarik dan artistik, saat ini banyak digunakan sebagai pendukung desain interior di hotel-hotel berbintang, spa, butik, dan perbankan. Anyaman Indonesia terkenal dimancanegara sebagai kerajinan dengan berbagai motif dan bentuk yang menarik. Setiap daerah memiliki ciri khas kerajinan bambu.

Media promosi yang dikelola dengan baik akan sangat membantu bagi kelangsungan usaha para pengrajin. Agustina (2015), menyatakan bahwa kerajinan diminati oleh negara Jepang, terbukti pada pameran Inacraft di Jakarta, terdapat $50 \%$ pengunjung adalah orang jepang. Tujuan ekspor kerajinan Indonesai selain Amerika dan Eropa adalah jepang. Hal ini memerlukan media promosi yang tepat. Misalnya katalog promosi di Garuda Indonesia, media promosi katalog harus ada pembaruhan mulai dari kerajinan apa saja yang terbaru, kemudian ada pemberitahuan secara jelas cara mendapatkan produk kerajinan tersebut," ucapnya. Hal tersebut membantu kita para pelaku industri kerajinan, bisa mencapai target pasar secara tepat dan efisien.

Penggunaan katalog mempermudah calon konsumen untuk mendapatkan informasi lengkap tanpa harus mendatangi tempat produsen. Konsumen dapat memilih dan menentukan produk mana yang akan dibeli, tanpa harus berkomunikasi langsung dengan produsen. Hal ini dimungkinkan terjadi karena katalog dilengkapi dengan rincian produk dan tentunya informasi detail mengenai produsen.

Katalog pada umumnya dilengkapi dengan informasi lengkap dikemas secara praktis, mudah dibawa, bahasa yang mudah dimengerti, menggunakan warna yang menarik dimata konsumen. Menurut Hasanah (2015), pada halaman pertama katalog berisi tentang gambaran produsen, visi misi produsen, contact person, kualitas dan teknologi yang digunakan, gambar tempat produksi, sistem produksi dan tenaga kerja. Bagian terpenting dari katalog adalah informasi rinci mengenai produk atau jasa yang dijual. Deskripsi detail tentang item produk dan harga serta tidak kalah penting adalah informasi tentang kontak alamat, nomer telepon, website, email, cabang 
atau anak perusahaan, metode pemesanan, pengiriman dan pembayaran, yang terakhir jam operasional produsen.

\section{METODE PENELITIAN}

Metode yang dilakukan dalam penelitian ini adalah metode kualitatif deskriptif. Penelitian kualitatif deskriptif ini merupakan penelitian yang menggunakan pendekatan studi kasus atau fokus dan intensif terhadap obyek tertentu sebagai suatu kasus. Yin (2002) menjelaskan bahwa pendekatan studi kasus memerlukan eksplorasi terhadap permasalahan yang ingin dijawab dan kontrol terhadap perilaku yang akan diteliti.

Penelitian dilakukan kepada para pengrajin bambu di desa Sukodono Sragen selama tahun 2015. Pengambilan data menggunakan focus group discussion (FGD). Kegiatan ini melibatkan pengrajin bambu di Desa Sukodono Kabupaten Sragen, akademisi, Balitbang Kabupaten Sragen, dan konsumen kerajinan bambu.

\section{HASIL DAN PEMBAHASAN}

\section{Kerajinan Bambu Sukodono}

Pengrajin bambu Sukodono umumnya adalah para petani yang memanfaatkan waktu luang untuk menambah pendapatan keluarga. "Para pengrajin tidak secara khusus mengerjakannya, hanya ketika ada waktu luang dari masa tanam, apalagi keahlian membuat kerajinan diperoleh secara turun temurun dan proses coba-coba" kata seorang warga. Masalah utama yang dihadapi adalah pemasaran.

Kerajinan bambu Sukodono Sragen selama ini mengandalkan pesanan sebagai proses pemasaran produknya. Menurut para pengrajin: "Jika ada orang pesan, baru para pengrajin membuat".

Lokasi pemasaran terbatas pada daerah sekitar Sragen saja. Show room hanya digunakan sebagai tempat produksi dan tempat mengambil barang pesanan. "Tidak banyak produk yang dipamerkan karena barang jadi langsung diambil oleh pemesan”. Menurut Lamb et. al (2001) menyatakan bahwa tempat atau lokasi penting bagi perusahaan. Beberapa alasan yang dikemukan adalah:
(1) tempat merupakan komitmen sumber daya jangka panjang yang dapat mengurangi fleksibilitas masa depan usaha, (2) lokasi akan mempengaruhi pertumbuhan usaha. Bahkan tidak terdapat dokumentasi dari produk yang pernah dibuat sebelumnya. Hal ini menyulitkan calon pembeli untuk dapat memilih kerajinan bambu yang diinginkan.

Kesulitan calon pelanggan dapat teratasi dengan jika pengusaha melakukan promosi melalui adanya katalog produk. Menutur Kotler dan Amstrong (2014), katalog promosi produk merupakan daftar informasi tentang produk-produk yang ditawarkan oleh perusahaan atau agen pemasaran. Katalog bertujuan agar memudahkan konsumen dalam memilih produk yang akan dibeli.

\section{Identifikasi Produk.}

Identifikasi produk kerajinan alam dapat diklasifikasikan dengan jenis bahan, fungsi, bentuk produk, warna dan bentuk hiasan. Kerajinan Bambu Produk kerajinan bambu yang selama ini dihasilkan oleh para pengrajin di desa Bendo diantaranya adalah: (a) Kotak Tempat Pernik-pernik: sebuah kotak perhiasan berbahan bambu, dengan ukuran $12 \mathrm{~cm}$ X $12 \mathrm{~cm}$ X $10 \mathrm{~cm}$. Harga RP7.500,00. Warna mengikuti permintaan pelanggan; (b) Tempat Tisue Lipat: alat rumah tangga sekaligus hiasan meja dengan aneka warna. Harga sangat terjangkau yaitu Rp.7.500,00; (c) Guci Bambu Tempat Perhiasan: produk ini diberi nama Cepuk Bambu. Ukuran diameter $12 \mathrm{~cm}$, tinggi $20 \mathrm{~cm}$. Berhias anyaman kulit bambu cantik beraneka warna dengan harga Rp.12.000,00; (d) Kap Lampu: berbentuk bulat, dengan diameter $30 \mathrm{~cm}$. Penggunaan kap lampu beranyam bambu membuat kesan cantik, eksotik dan menyatu dengan alam. Produk ini banyak diminati oleh restoran, hotel ataupun penginapan.

\section{Katalog Produk Bambu Sukodono Sragen}

Langkah selanjutnya yaitu pembuatan katalog sebagai media promosi telah dilakukan oleh pengrajin bambu Sukodono Sragen. Tujuan pembuatan katalog bagi pengrajin bambu ini adalah untuk mempertahankan pelanggan yang sudah ada dan menjaring calon pelanggan baru. Katalog terdiri dari informasi mengenai produsen kerajinan 
seperti nama, alamat dan nomer telepon yang bisa dihubungi serta tidak kalah penting adalah kuantitas dan kualitas produk yang akan ditawarkan. Adapun bentuk katalog yang telah dibuat adalah sebagai berikut:

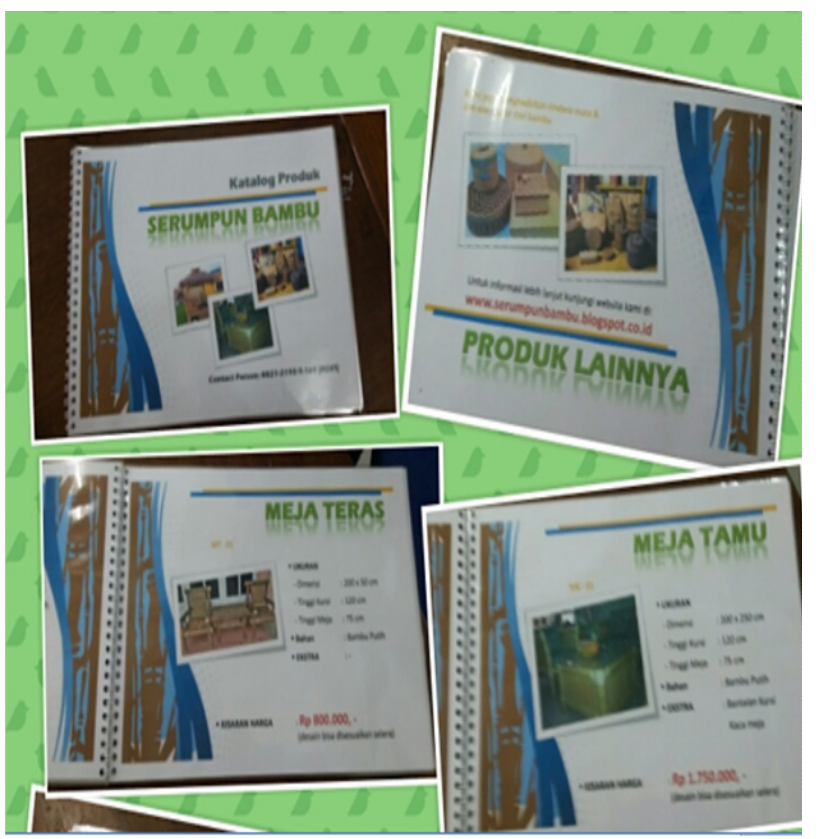

Dalam katalog tersebut berisi antara lain:

1. Cover Depan berisi Nama Kelompok Pengrajin yaitu Serumpun Bambu dan Contact Person yaitu pak Rofi selaku Bapak Angkat

2. Halaman Isi yang terdiri Produk yang ditawarkan: (a) Gazebo 1. Ukuran diameter atap $150 \mathrm{~cm}$, diameter meja 120 $\mathrm{cm}$. Atap berbahan jerami dan didominasi oleh bambu petung. Dilengkapi pula dengan 6 kursi; (b) Gazebo 2. Atap jerami berukuran $200 \times 200 \mathrm{~cm}$, ukuran base atau landasan 180x200cm. Ekstra meja kursi panjang. Kisaran harga Rp.2.000.000,00. Produk ini diminati pelanggan yang memiliki rumah makan, hotel ataupun tempat rekreasi (c) Meja Makan. Ukuran dimensi 200x200cm, tinggi kursi $120 \mathrm{~cm}$, tinggi meja $100 \mathrm{~cm}$. Bahan didominasi bambu Tutul, anyaman kulit bambu, dan ekstra kaca meja. Harga yang ditawarkan berkisar Rp.1.250.000,00; (d) Lemari Pakaian. Dimensi 150x50x200cm. Produk ini dibuat dengan bahan baku bambu Putih. Harga lemari pakaian antara Rp.850.000,00 (lemari tanpa kaca) dan Rp.1.100.00,00 dilengkapi dengan kaca lemari; (e) Meja Tamu 1. Dimensi 200x250cm, tinggi kursi $120 \mathrm{~cm}$ dan tinggi meja $75 \mathrm{~cm}$ menggunakan bahan baku bambu Putih. Produk ini menarik karena dilengkapi dengan bantalan kursi sehingga membuat nyaman pengguna dan dipercantik dengan kaca meja. Harga satu set meja ini hanya Rp.1.750.000,00. Warna bisa disesuaikan dengan selera konsumen. Satu set meja yang lebih kecil hanya berkisar Rp.1.200.000,00 (f) Meja teras dimensi 200x50 cm, tinggi kursi $120 \mathrm{~cm}$ dan tinggi meja $75 \mathrm{~cm}$, berbahan bambu putih dengan harga Rp.750.000,00 sampai dengan Rp.800.000,00; (g) Meja Rias. Ukuran berdimensi 150x50x180cm. Bahan bambu putih dan tentunya dilengkapi kaca cantik ditambah pula dengan bantalan kursi.(h) Produk Bambu Lainnya seperti tempat penyimpanan barang, tempat baju kotor, hiasan meja dll. Dibuat selain untuk alat serba guna sekaligus mempercatik ruangan.

3. Cover Belakang yang berisi alamat KUB Serumpun Bambu. Terletak di Bendo, Sukodono, Kabupaten Sragen. No telp 082121089169 atas nama Rofi. Dapat pula mengakses website www. serumpunbambu.blogspot.co.id

\section{Promosi Produk Kerajinan Bambu Melalui Katalog}

Penyusunan katalog yang maksimal, lengkap dengan informasi mengenai produsen dan rincian produk masih kurang jika tanpa didukung oleh keaktifan tenaga penjual dalam menyampaikan katalog ke tangan calon konsumen. Katalog KUB Serumpun Bambu dibagikan kepada berbagai restoran, hotel, penginapan dan tempat rekreasi. Setelah adanya katalog penjualan, area penjualan produk KUB Serumpun Bambu mengalami perluasan. Pada awalnya hanya berhasil dijual di dalam wilayah Kabupaten Sragen, sekarang meluas ke wilayah Kabupaten Sragen, Magelang, Semarang dan Jakarta. Penjualan meningkat mencapai $20 \%$ dibandingkan sebelum menggunakan katalog. Konsumen mendapatkan kemudahan dalam memilih produk melalui katalog. Hal ini sejalan dengan pernyataan Kotler dan Amstrong (2014), yaitu konsumen mudah memilih produk hanya dengan menggunakan katalog produk. 
Strategi pemasaran melalui katalog terbukti dapat meningkatkan penjualan produk dari suatu usaha.

Namun pelaksanaan penjualan produk kerajinan bambu masih mengalami kelemahan. Katalog konvensional berbentuk hardcopy ini masih tergantung pada aktif atau tidaknya tenaga penjual. Tenaga penjual KUB Serumpun Bambu masih sedikit sehingga area yang dicapai masih terbatas. Kelemahan penggunaan katalog konvensional yaitu paperless dan ditambah banyaknya penjualan produk sejenis berbasis on line.Pemasaran on line disini termasuk dalam pemasaran langsung.

\section{SIMPULAN}

Strategi pemasaran yang tepat sangat diperlukan bagi pertumbuhan UMKM khususnya industri kerajinan bambu. Salah satunya yaitu penggunaan katalog sebagai media promosi. Agar target pemasaran tercapai maka penyusunan katalog sebaiknya dapat menjawab semua pertanyaan dari pelanggan mengenai produk atau dengan kata lain dapat mewakili produk kerajinan bambu yang akan ditawarkan.

Keterbatasan dari penelitian ini adalah hasil penerapan katalog sebagai media promosi kerajinan bambu belum bisa dilihat, karena membutuhkan waktu yang cukup lama, serta komitmen dari pengrajin untuk aktif menawarkan produk melalui katalog yang sudah disusun. Selain katalog sebagai media promosi, adapun saran yang bisa diajukan bagi pengrajin bambu antara lain:

1. Melakukan strategi penetrasi pasar. Optimalisasi penjualan produk pada wilayah yang sudah ada. Hal ini dilakukan dengan cara "jemput bola" kepada calon konsumen, yaitu dengan menawarkan produk secara langsung. penggunaan katalog yang menarik dan lengkap, sehingga memudahkan calon pelanggan untuk memilih produk.

2. Melakukan perluasan pasar. Cara yang dapat ditempuh dalam perluasan pasar produk kerajinan bambu adalah 1) membentuk jaringan pemasaran dengan pemilik kios furniture ataupun kerajinan bambu di daerah lain. 2) menjalin kerjasama dengan Pemerintah Daerah Kabupaten Sragen untuk dapat mengikuti pameran.

3. Membuat katalog on line. Penggunaan internet saat ini merupakan senjata yang ampuh bagi para pelaku promosi. Kemudahan untuk mengakses internet, memilih produk sampai kemudahan pada proses pemesanan menjadi daya tarik tersendiri bagi calon pelanggan. Hal ini juga berguna untuk menghilangkan kelemahan paperless dari katalog konvensional dan memberikan nilai tambah pada produk yang ditawarkan melalui tat kelola komunikasi visual berbasis desain grafis.

\section{DAFTAR PUSTAKA}

Wijaya et al, 2004, Identifikasi jenis-jenis bambu di Pulau Sumba Kecil. Bidang Botani Pusat Penelitian Biologi LIPI. Cibinong

Fredicksson, Wadstrom, Medbo., 2014. Assuring materials avaibility during the prediction transfer process, DOI. 10.1108/JM T M-02-2012-0016. Journal of manufacturing Technology Management, Vol. 25 No. 3. Pp 310.333. Emerald Group Publishing Limited

Fang-Wu Tung., 2012. Weaving with rush: Exploring Craft-Design Collaborations in Revitalizing a Local Craft. International Journal of Design Vol. 6 No. 3

Frances., 1998, The Challenges in changing catalog business: Selling Promotional Products Through the Mail. Direct Marketing. April. 60.12. Proquest Research Library. Pg 23

Hasanah K, 2015, Promosi Katalog Harga dan Keputusan Pembelian di Indomaret, studi kasus pada konsumen Indomaret Kota Madiun. JIBEKA, Volume 9 
Nomor 1 Februari 2015. 65-69

Kotler dan Keller., 2009. Manajemen Pemasaran. PT. Indeks. Jakarta

Titin Agustina., 2015http://www.jurnalasia. com/2015/04/11/produk-kerajinanindonesia-digandrungi-buyer-jepang/
Tjiptono., 2004. Strategi Pemasaran, edisi kedua, Andi, Yogyakarta

Yin R. K., 2002. Case Study Research-Design and Methods, Sage, Thousand Oaks, CA 


\title{
PENGARUH UKURAN PERUSAHAAN, PROFITABILITAS, KEBIJAKAN DEVIDEN, DAN KEPUTUSAN INVESTASI TERHADAP NILAI PERUSAHAAN (Studi Penggunaan Indeks Lq-45 Periode 2010 -2014)
}

\author{
Henri Dwi Wahyudi' ${ }^{1}$ Chuzaimah ${ }^{2}$, dan Dani Sugiarti ${ }^{3}$ \\ Fakultas Ekonomi Dan Bisnis Universitas Muhammadiyah Surakarta. \\ 1Email: hdw122@ums.ac.id, \\ ${ }^{2}$ Email: chuzaimah@ums.ac.id, \\ ${ }^{3}$ Email: dani.sugiarti@gmail.com
}

\begin{abstract}
A company aimed and tried to maximize shareholder prosperity. Shareholder prosperity was reflected by company value. This study aimed to review the effect of firm size, Dividend Payout Ratio, Return on Equity, and Price Earning Ratio on firm value among ILQ45 companies registered in The Indonesia Stock Exchange. Populations of this study were firms registered in The Indonesia Stock Exchange of the year 2010 - 2014. The research used purposive sampling method based on determined criteria. There were 22 firms with totally 110 data. After the outliers process, there were 18 with totally 90 data samples. Based on these data, this study carried a classic assumption analysis using multiple regression data with SPSS16. The regression test resulted: (1) Firm size positively influenced and not significant to firm value; (2) Dividend Payout Ratio positively influenced and not significant to firm value; (3) Return on Equity positively influenced and not significant to firm value; (4) Price Earning Ratio positively influenced and not significant to corporate value.
\end{abstract}

Keyword: firm size, dividend payout ratio, return on equity, price earning ratio, firm value

\begin{abstract}
Abstraksi: Perusahaan bertujuan untuk memaksimalkan kemakmuran pemegang sahan melalui usaha yang dilakukannya. Kemakmuran pemegang saham akan tercermin dari nilai perusahaan tersebut. Penelitian ini bertujuan untuk menguji pengaruh Ukuran Perusahaan, Deviden Payout Ratio (DPR), Retrun On Equity (ROE), dan Price Earning Ratio (PER) terhadap Nilai Perusahaan studi empiris pada perusahaan ILQ45 yang terdaftar di Bursa Efek Indonesia. Populasi dalam penelitian ini adalah seluruh perusahaan ILQ45 yang terdaftar di Bursa Efek Indonesia dari tahun 2010 - 2014. Metode yang digunakan untuk pengambilan sampel adalah dengan cara purposive sampling berdasar kriteria yang telah ditentukan. Jumlah sampel dalam penelitian ini sebanyak 22 perusahaan dengan 110 data. Setelah terjadi outliers data, sampel yang digunakan sebanyak 18 Perusahaan dengan 90 data. .Data tersebut kemudian dilakukan pengujian asumsi klasik dan dianalisis menggunakan analisis data Regresi Berganda dengan SPSS16. Berdasarkan hasil penelitian pada model regresi disimpulkan bahwa: (1)variabel (variabel Firm Size berpengaruh positif dan tidak signifikan terhadap nilai perusahaan (2)variabel Deviden Payout Ratio(DPR) berpengaruh positif dan tidak signifikan terhadap nilai perusahaan, (3) Retrun On Equity (ROE) berpengaruh positif dan signifikan terhadap nilai perusahaan, (4)variabel Price Earning Ratio (PER) berpengaruh positif dan signifikan terhadap nilai perusahaan.
\end{abstract}

Kata kunci: ukuran perusahaan, deviden payout ratio(DPR) retrun on equity(ROE), price earning ratio (PER ), nilai perusahaan

\section{PENDAHULUAN}

Bagi Perusahaan yang telah go public, memaksimalkan nilai Perusahaan dapat tercermin dari harga saham yang tinggi. Nilai Perusahaan menjadi penting karena dapat mengambarkan keadaan Perusahaan. Dengan baiknya nilai perusahan, calon investor akan memandang baik Perusahaan tersebut karena nilai Perusahaan yang tinggi mencerminkan kinerja Perusahaan yang baik. Selain itu nilai Perusahaan dapat mengambarkan prospek serta harapan akan kemampuan dalam meningkatkan kekayaan Perusahaan di masa mendatang.

Ukuran sebuah perusahaan (firm size) dianggap mampu mempengaruhi nilai perusahaan. Hal tersebut dikarenakan 
semakin besar ukuran perusahaan maka perusahaan tersebut akan semakin mudah dalam memperoleh sumberdana. Dana tersebut kemudian akan dikelola oleh pihak manajemen untuk meningkatkan nilai perusahaan. Henurut Sujoko (2007) dalam Maryam (2014) ukuran perusahaan yang besar mengalami perkembangan sehingga investor akan merespon positif dan nilai perusahaan akan meningkat.

Nilai perusahaan dapat dilihat dari kemampuan perusahaan membayar deviden. Kebijakan deviden yang optimal adalah kebijakan yang menciptakan keseimbangan antara deviden saat ini dan pertumbuhan di masa mendatang sehingga memaksimumkan harga saham (Brigham dan Houston, 2001 : 198). Deviden menjadi salah satu alasan bagi investor dalam menanamkan investasinya, sebab deviden merupakan pengembalian atas investasi pada perusahaan tersebut. Para investor mempunyai tujuan utama yaitu meningkatkan kesejahteraannya lewat pengembalian deviden, sedangkan perusahaan bertujuan untuk mempertahankan keberlanjutan hidup perusahaan serta mensejahterakan pemegang saham.

Keputusan yang penting lainnya di dalam perusahaan adalah keputusan investasi. Hal tersebut karena keputusan investasi berkaitan hasil keuntungan yang diperoleh perusahaan di masa yang akan datang. Fama (1978), Septia (2015) menyatakan bahwa nilai perusahaaan semata-mata ditentukan oleh keputusan investasi. Dari pernyataan tersebut dapat diartikan bahwa keputusan investasi menjadi penting karena dalam mencapai tujuan perusahaan akan dihasilkan melalui kegiatan investasi perusahaan. Hal ini mendorong peneliti untuk melakukan analisis mengenai faktor-faktor yang mempengaruhi nilai perusahaan.

Peneliti mencoba menggunakan data Index LQ 45, Indeks LQ 45 adalah nilai kapitalisasi pasar dari 45 saham yang paling likuid dan memiliki nilai kapitalisasi yang besar hal itu merupakan indikator likuidasi. Indeks LQ 45, menggunakan 45 saham yang terpilih berdasarkan Likuiditas perdagangan saham dan disesuaikan setiap enam bulan (setiap awal bulan Februari dan Agustus).

\section{RUMUSAN MASALAH}

Rumusan masalah yang diajukan peneliti adalah sebagai berikut :

1. Apakah profitabilitas berpengaruh terhadap nilai Perusahaan.

2. Apakah Ukuran Perusahaan (firm size) berpengaruh terhadap nilai Perusahaan.

3. Apakah kebijakan deviden berpengaruh terhadap nilai Perusahaan.

4. Apakah keputusan investasi berpengaruh terhadap nilai Perusahaan.

\section{TUJUAN PENELITIAN}

Penelitian yang akan dilakukan ini bertujuan antara lain :

1. Mengetahui pengaruh profitabilitas terhadap nilai Perusahaan.

2. Mengetahui pengaruh firm size terhadap nilai Perusahaan.

3. Mengetahui pengaruh kebijakan deviden terhadap nilai Perusahaan.

4. Mengetahui pengaruh keputusan Investasi terhadap nilai Perusahaan.

\section{PENELITIAN TERDAHULU.}

1. Jusriani dan Shidiq (2013) melakukan penenelitian mengenai analisis pengaruh profitabilitas, kebijakan deviden, kebijakan hutang, dan kepemilikan manajerial terhadap nilai perusahaan manufaktur yang terdaftar di BEI . Hasil penelitian menunjukkan bahwa secara parsial, profitabilitas dan kebijakan deviden berpengaruh signifikan dengan arah positif terhadap nilai perusahaan. Sedangkan kebijakan hutang dan kepemilikan manajerial tidak berpengaruh yang signifikan terhadap nilai perusahaan.

2. Leni dan Erma Setyawati (2014) meneliti analisis pengaruh profitabilitas, kebijakan deviden, kebijakan hutang, dan kepemilikan manajerial terhadap nilai perusahaan pada sektor industri manufaktur di BEI. Hasil penelitian menunjukkan bahwa secara parsial, profitabilitas berpengaruh positif dan signifikan terhadap nilai perusahaan. Sedangkan kebijakan deviden 
berhubungan positif namun tidak berpengaruh terhadap nilai perusahaan, sedangkan kebijakan hutang dan kepemilikan manajerial berhubungan negative dan tidak berpengaruh terhadap nilai perusahaan.

3. Maryam, Siti (2014) melakukan peneitian berjudul analisis pengaruh firm size, growth, leverage dan profitabilitas terhadap nilai perusahaan manufaktur yang terdaftar di BEI periode tahun 20082012. Hasil penelitian menunjukkan bahwa secara parsial, firm size, growth, leverage dan profitabilitas berpengaruh yang positif signifikan terhadap nilai perusahaan.

\section{KERANGKA PEMIKIRAN DAN PENGEMBANGAN HIPOTESIS}

\section{Kerangka Pemikiran}

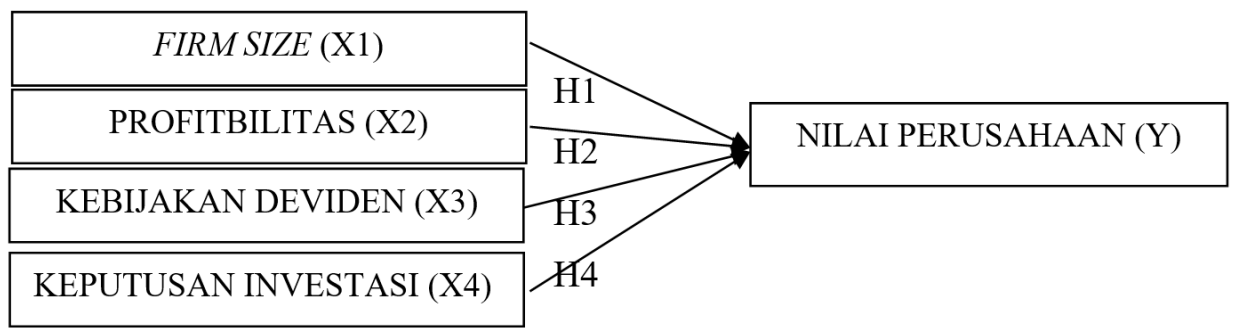

\section{Pengaruh Firm Size Terhadap Nilai Perusahaan}

Menurut Riyanto (2001) dalam Maryam (2014) ukuran Perusahaan dapat diartikan sebagai besar kecilnya Perusahaan diihat dari besarnya nilai equity, nilai Perusahaan, ataupun hasil nilai total aktiva dari suatu Perusahaan. Perusahaan yang lebih besar akan dapat dengan mudah mengakses pasar modal dalam memperoleh pendanaan yang lebih besar untuk Perusahaannya, sehingga Perusahaan mampu mempunyai rasio pembayaran dividen yang lebih tinggi dibandingkan Perusahaan kecil.

Hasil penelitian Maryam (2014) menyatakan bahwa Firm Size berpengaruh terhadap Nilai Perusahaan. Berdasarkan uraian tersebut, maka dapat dirumuskan hipotesis sebagai berikut :

H1: Firm Size berpengaruh tehadap nilai Perusahaan

\section{Pengaruh Return On Equity (ROE) Terhadap Nilai Perusahaan}

Profitabilitas menurut Sartono (1997) dalam Septia (2015) adalah kemampuan Perusahaan memperoleh laba dalam hubungan dengan penjualan, total aktiva maupun modal sendiri. Rasio profitabilitas akan menggambarkan mengenai tingkat efektifitas pengelolaan suatu Perusahaan.
Semakin tinggi profitabilitas suatu Perusahaan berarti semakin baik, karena kemakmuran pemegang atau pemilik saham meningkat dengan semakin tingginya profitabilitas Perusahaan tersbut.

Hasil penelitian Astuti dan Setyawati (2014) menyatakan bahwa profitabilitas berpengaruh terhadap Nilai Perusahaan. Berdasarkan uraian tersebut, maka dapat dirumuskan hipotesis sebagai berikut :

H2: Profitabilitas berpengaruh tehadap Nilai Perusahaan

\section{Pengaruh Kebijakan Deviden Terhadap Nilai Perusahaan}

Salah satu bentuk pengembalian yang akan diperoleh pemilik saham adalah deviden. Deviden adalah laba setelah pajak yang dibagikan kepada pemilik dan pemegang saham. Kebijakan deviden sering dianggap sebagai bagian dari keputusan pembelanjaan, khususnya pembelanjaan internal. Hal ini terjadi karena besar kecilnya deviden yang akan dibayarkan akan mempengaruhi sumber dana internal Perusahaan, yaitu laba ditahan. Semakin besar deviden yang dibayarkan kepada pemegang saham, maka semakin kecil laba ditahan, dan sebaliknya. Penentuan besaran bagian laba bersih Perusahaan yang akan dibagikan sebagai deviden merupakan 
kebijakan manajemn Perusahaan, serta akan memengaruhi nilai Perusahaan serta harga saham (Sudana, 2011:167).

Hasil penelitian Jusriani dan Nur (2013) menyatakan bahwa Kebijakan Deviden berpengaruh terhadap Nilai Perusahaan. Berdasarkan uraian tersebut, maka dapat dirumuskan hipotesis sebagai berikut :

H3: Kebijakan Deviden berpengaruh tehadap Nilai Perusahaan

\section{Pengaruh Keputusan Investasi Terhadap Nilai Perusahaan}

Tandelilin (2001) dalam Septia (2015) mengemukakan bahwa investasi adalah komitmen atas sejumlah dana atau sumber daya lainnya yang dilakukan saat ini, dengan tujuan memperoleh keuntungan di masa datang. Maka manajer berusaha sebaik mungkin untuk mengambil peluang-peluang tersebut demi memaksimalkan kesejahteraan pemegang saham karena semakin besar kesempatan dalam investasi yang member keuntungan maka investasi yang dilakukan akan semakin besar.

Hasil penelitian Septia(2015) menyatakan bahwa Keputusan Investasi berpengaruh terhadap Nilai Perusahaan. Berdasarkan uraian tersebut, maka dapat dirumuskan hipotesis sebagai berikut :

H4: Keputusan investasi berpengaruh tehadap nilai Perusahaan.

\section{POPULASI, SAMPEL DAN TEKNIK PENGAMBILAN SAMPEL}

Populasi yang digunakan adalah seluruh Perusahaan yang terdaftar di BEI tahun 2010 $-2014$.

Sampel yaitu semua Perusahaan yang masuk terus menerus dalam perhitungan ILQ45 periode tahun 2010 sampai dengan 2014. Teknik pengambilan sampel dalam penelitian ini adalah purposive sampling.

Tabel 1.

Sampel yang memenuhi kreteria

\begin{tabular}{lc}
\hline \multicolumn{1}{c}{ Keterangan } & Jumlah \\
\hline Jumlah Perusahaan ILQ45 yang terdaftar di BEI selama tahun 2010-2014 & 45 \\
Perusahaan yang tidak terdaftar secara berturut-turut & 23 \\
Perusahaan yang tidak menerbitkan laporan keuangan secara lengkap & - \\
Jumlah Sampel & 22 \\
Data Perusahaan yang diolah $=22$ x 5 tahun periode & 110 \\
Setelah terjadi outlier & 20 \\
Jumlah sampel setelah outlier & 90 \\
\hline Sumber : Data diolah. &
\end{tabular}

\section{DEFINISI OPERASIONAL VARIABEL DAN PENGUKURAN VARIABEL}

Berdasarkan hipotesis yang telah dirumuskan, maka variabel-variabel yang akan dianalisis adalah sebagai berikut :

Tabel 2

Definisi operasional variabel

\begin{tabular}{llll}
\hline & Jenis Variabel & & \multicolumn{1}{c}{ Proksi } \\
\hline Variabel dependen & Nilai Perusahaan & $\mathrm{Y}$ & Price to Book Value Ratio (PBV) \\
& Ukuran Perusahaan & $\mathrm{X}_{1}$ & Size = Ln of Total Aktiva \\
Variabel & Kebijakan Deviden & $\mathrm{X}_{2}$ & Deviden Payout Ratio (DPR) \\
independen & Profitabilitas & $\mathrm{X}_{3}$ & Return On Equity (ROE) \\
& Keputusan Investasi & $\mathrm{X}_{4}$ & Price Earnings Ratio (PER) \\
\hline
\end{tabular}

Sumber : data hipotesis. 


\section{ANALISIS DATA}

Dalam penelitian ini metode analisis data yang digunakan adalah teknik analisis regresi berganda atau multiple regression untuk menguji Ukuran Perusahaan, pengaruh $R O E$, $D P R, P E R$ terhadap Nilai Perusahaan. Asumsiasumsi yang digunakan : uji normalitas, uji multikolenieritas, uji autokorelasi, dan uji heteroskedastisitas.

\section{Pengujian Asumsi Klasik}

Uji asumsi klasik dilakukan terhadap data yang digunakan untuk analisis regresi berganda. Uji asumsi klasik yang digunakan oleh peneliti terdiri dari normalitas, autokorelasi, heteroskedastisitas, dan multikolenieritas, dan semua ukurannya baik.

\section{Uji Hipotesis}

\section{Analisis Regresi Linier Berganda}

Persamaan model regresi digunakan untuk mengetahui pengaruh variabel $\mathrm{X}$ terhadap variabel Y. Berdasarkan pengujian data, hasil regresi berganda untuk menguji pengaruh FSZ, ROE, DPR dan PER terhadap Nilai Perusahaan. Bentuk umum persamaan regresi linier berganda

Tabel 3

Hasil Uji Regresi Linier Berganda

\begin{tabular}{|c|c|c|c|c|c|c|}
\hline & \multirow{2}{*}{$\begin{array}{c}\text { Model } \\
\text { B }\end{array}$} & \multicolumn{2}{|c|}{$\begin{array}{c}\text { Unstandardized } \\
\text { Coefficients }\end{array}$} & \multirow[t]{2}{*}{$\begin{array}{c}\text { Standardized } \\
\text { Coefficients }\end{array}$} & \multirow{2}{*}{$\mathbf{t}$} & \multirow{2}{*}{ Sig. } \\
\hline & & $\begin{array}{l}\text { Std. } \\
\text { Error }\end{array}$ & Beta & & & \\
\hline \multirow{5}{*}{1} & (Constant) & -2.457 & 1.548 & & -1.588 & .116 \\
\hline & $\mathrm{X} 1$ & .038 & .046 & .052 & .834 & .407 \\
\hline & $\mathrm{X} 2$ & .072 & .011 & .390 & 6.426 & .000 \\
\hline & $\mathrm{X} 3$ & .000 & .002 & -.018 & -.300 & .765 \\
\hline & $\mathrm{X} 4$ & .173 & .014 & .770 & 12.356 & .000 \\
\hline
\end{tabular}

Sumber : Hasil Pengolahan Data Statistik 2016.

Dari tabel tersebut, maka dapat dibentuk suatu persamaan regresi dengan model taksiran sebagai berikut :

$$
\mathrm{PBV}=\mathrm{FSZ}+\mathrm{ROE}+\mathrm{DPR}+\mathrm{PER}+\mathrm{e}
$$

Keterangan :

$$
\begin{array}{ll}
P B V & =\text { Nilai Perusahaan } \\
\alpha & =\text { konstanta } \\
F S Z & =\text { Firm Size } \\
R O E & =\text { Retrun On Equity } \\
D P R & =\text { Deviden Payout Ratio } \\
P E R & =\text { Price Earning Ratio } \\
\mathrm{e} & =\text { kesalahan penggangu (error) }
\end{array}
$$

Berdasarkan hasil regresi tersebut diatas dapat diinterprestasikan sebagai berikut :

1. Konstanta sebesar -2.457 menunjukan bahwa faktor ROE, FSZ, DPR dan PER konstan maka harga saham akan turun sebesar -2.457 .
2. Koefisien regresi firm size bernilai positif yaitu 0, 038 menunjukkan bahwa setiap ada kenaikan firm size sebesar 1\% maka harga saham akan naik sebesar 0,038. Sebaliknya setiap setiap ada penurunan firm size sebesar 1\% maka harga saham akan turun sebesar 0,038.

3. Koefisien regresi $R O E$ bernilai positif yaitu 0, 072 menunjukkan bahwa setiap ada kenaikan $R O E$ sebesar $1 \%$ maka harga saham akan naik sebesar 0, 072. Sebaliknya setiap ada penurunan $R O E$ sebesar 1\% maka harga saham akan turun sebesar 0, 072.

4. Koefisien regresi $D P R$ bernilai positif yaitu 0, 000 menunjukkan bahwa setiap ada kenaikan DPR sebesar 1\% maka harga saham akan naik sebesar 0,000 . Sebaliknya setiap ada penurunan $D P R$ sebesar $1 \%$ maka harga saham akan turun sebesar 0,000 . 
5. Koefisien regresi EPS bernilai positif yaitu 0,173 menunjukkan bahwa setiap ada kenaikanEPS sebesar $1 \%$ maka harga saham akan naik sebesar 0, 173 . Sebaliknya setiap ada penurunan EPS sebesar 1\% maka harga saham akan turun sebesar 0, 173 .

\section{Uji Koefisien Determinasi (R Square)}

Koefisien determinasi digunakan untuk mengukur seberapa jauh kemampuan model dalam menerangkan variasi variabel-variabel dependen. Hasil Uji koefisien determinasi tampak pada tabel di bawah ini.

Tabel 4

Uji Koefisien Determinasi

\begin{tabular}{cccc}
\hline Model & R & R Square & Adjusted R Square \\
\hline 1 & 0.834 & 0.695 & 0.681 \\
\hline Sumber : Hasil Pengolahan Data Statistik 2016. &
\end{tabular}

Dari tabel diatas dapat ditarik kesimpulan bahwa pengaruh semua variabel independen adalah $69,5 \%$ dan sisanya 30,5 $\%$ dipengaruhi oleh variabel lain selain variabel independen yang digunakan dalam penelitian ini.

\section{Uji Pengaruh Simultan (F test)}

Uji $F$ digunakan untuk menguji apakah dua sampel atau lebihdari populasi dengan varian yang sama, dan distibusi tersebut digunakan untuk membandingkan dua atau lebih rata-rata populasi secara simultan.
Hasil pengujian tersebut seperti di dalam tabel 5.

Dari hasil perhitungan menunjukkan bahwa nilai $\mathrm{F}_{\text {hitung }}$ lebih besar dibandingkan nilai $F_{\text {tabel }}$ yaitu $48.446>2,71$ dan nilai signifikasi $\mathrm{F}$ lebih kecil dibandingkan level of significant yang digunakan dalam penelitian sekarang yaitu $0,000<0,05$.. Artinya bahwa secara bersama-sama (simultan) variabel bebas yang terdiri dari Return On Equity(ROE), Firm Size, Deviden Payout Ratio (DPR), Price Earning Ratio (PER) berpengaruh terhadap Nilai Perusahaan $(P B V)$.

Tabel 5

Hasil Uji F (Simultan)

\begin{tabular}{ccccc}
\hline Variabel & $\mathrm{F}_{\text {hitung }}$ & $\mathrm{F}_{\text {tabel }}$ & Sig. & Keterangan \\
\hline $\begin{array}{c}\text { FSZ , ROE, DPR } \\
\text { PER }\end{array}$ & 48.446 & 2,71 & 0,000 & Signifikan \\
\hline
\end{tabular}

Sumber : Hasil Pengolahan Data Statistik 2016

\section{Uji Parsial (t test)}

Uji $\mathrm{t}$ digunakan untuk menguji beda dua rata-rata terhadap $\mathrm{H}_{0}$ dan $\mathrm{H}_{1}$ dengan tingkat kesalahan 5\%, jika nilai probabilitas yang didapat ( $t$ hitung) lebih besar daripada perbandingan probabilitas maka $\mathrm{H}_{0}$ ditolak dan $\mathrm{H}_{1}$ diterima dan apabila lebih kecil dari perbandingan probabilitas maka $\mathrm{H}_{0}$ diterima dan $\mathrm{H}_{1}$ ditolak.

Tabel 6

Hasil Uji t (parsial)

\begin{tabular}{cccc}
\hline Model & $\mathbf{T}_{\text {tabel }}$ & $\mathbf{t}_{\text {hitung }}$ & Sig. \\
\hline X1 & 1,98 & 0.834 & 0.407 \\
X2 & 1,98 & 6.426 & 0.000 \\
X3 & 1,98 & -0.300 & 0.765 \\
X4 & 1,98 & 12.356 & 0.000 \\
\hline
\end{tabular}

Sumber : Hasil Pengolahan Data Statistik 2016 
Dari hasil analisis regresi diatas dapat dilihat bahwa keempat variabel independen hanya 2 (dua) variabel yang tidak berpengaruh signifikan yaitu x1dan x3 yaitu Firm size dan Deviden Payout Ratio dengan tingkat signifikansi 0,407 dan 0,765 sedangkan 2 (dua) variabel lainnya yaitu $\mathrm{x} 2$ dan $\mathrm{x} 4$ yaitu $R O E$ dan $P E R$ dinyatakan signifikan dengan nilai Sig sebesar 0.000. Hal ini dikarenakan nilai Sig t variabel lebih kecil dari tingkat signifikasi sebesar 0,05 atau $5 \%$.

Dari hasil pengujian tersebut maka dapat diinterprestasikan sebagai berikut ini:

1. Nilai Signifikansi Variabel Firm Size

Bahwa Firm Size memiliki nilai signifikasi lebih besar dibandingkan level of significant yaitu sebesar $0.407>0,05$ dan nilai $t_{\text {hitung }}$ sebesar 0.834 lebih kecil dibandingkan dengan nilai $\mathrm{t}_{\text {tabel }}$ sebesar 1,98. Hal ini berarti menunjukkan secara individu variabel Firm Size tidak terdapat pengaruh terhadap nilai Perusahaan dan mempunyai hubungan positif terhadap nilai Perusahaan. Dengan demikian dapat disimpulkan bahwa Hipotesis Kedua $\left(\mathrm{H}_{2}\right)$ ditolak.

2. Nilai Signifikansi Variabel Retrun On Equity (ROE)

Bahwa Retrun On Equity (ROE) memiliki nilai signifikasi lebih kecil dibandingkan level of significant yaitu sebesar $0.000>$ 0,05 dan nilai $t_{\text {hitung }}$ sebesar 6.426 lebih besar dibandingkan dengan nilai $t_{\text {tabel }}$ sebesar 1.98. Hal ini berarti menunjukkan secara individu variabel $R O E$ terdapat pengaruh terhadap Nilai Perusahaan dan mempunyai hubungan positif terhadap nilai Perusahaan. Dengan demikian dapat disimpulkan bahwa Hipotesis Pertama $\left(\mathrm{H}_{1}\right)$ diterima.

3. Nilai Signifikansi Variabel Deviden Payout Ratio (DPR)

Bahwa Deviden Payout Ratio (DPR) memiliki nilai signifikasi lebih kecil dibandingkan level of significant yaitu sebesar $0.765>0,05$ dan nilai $t_{\text {hitung }}$ sebesar -0.300 lebih kecil dibandingkan dengan nilai $\mathrm{t}_{\text {tabel }}$ sebesar $1.98 \mathrm{Hal}$ ini berarti menunjukkan secara individu variabel $D P R$ tidak terdapat pengaruh terhadap nilai Perusahaan dan mempunyai hubungan positif terhadap nilai Perusahaan. Dengan demikian dapat disimpulkan bahwa Hipotesis Ketiga $\left(\mathrm{H}_{3}\right)$ ditolak.

4. Nilai Signifikansi Variabel Price Earning Ratio (PER)

Bahwa Price Earning Ratio (PER) memiliki nilai signifikasi lebih kecil dibandingkan level of significant yaitu sebesar $0,000>0,05$ dan nilai $t_{\text {hitung }} 12.356$ sebesar lebih besar dibandingkan dengan nilai $t_{\text {tabel }}$ sebesar 1,98. Hal ini berarti menunjukkan secara individu variabel PER terdapat pengaruh terhadap nilai Perusahaan dan mempunyai hubungan positif terhadap nilai Perusahaan. Dengan demikian dapat disimpulkan bahwa Hipotesis Keempat $\left(\mathrm{H}_{4}\right)$ diterima.

\section{PEMBAHASAN}

\section{Pengujian Ukuran Perusahaan (Firm Size) terhadap Nilai Perusahaan}

Pengujian hipotesis pertama $\left(\mathrm{H}_{1}\right)$ dilakukan untuk menguji apakah $F S$ mempunyai pengaruh terhadap Nilai Perusahaan.

Penelitian ini menerima hipotesis bahwa Firm Size (FS) berpengaruh terhadap nilai perusahaan $(P B V)$. Hasil penelitian ini sejalan dengan penelitian yang dilakukan Maryam, Sitti (2014) yang mengatakan bahwa variable Firm Size (FS) mempunyai pengaruh terhadap nilai perusahaan $(P B V)$. Sehingga dapat disimpulkan bahwa semakin besar ukuran perusahaan akan menjadikan perusahaan akan semakin fleksibel dan mudah dalam memperoleh dana namun menyebabkan kekhawatiran pihak pemilik saham atas asset yang dimilikinya.

\section{Pengujian Retrun On Equity (ROE) terhadap Nilai Perusahaan}

Pengujian hipotesis kedua $\left(\mathrm{H}_{2}\right)$ dilakukan untuk menguji apakah $R O E$ mempunyai pengaruh terhadap Nilai Perusahaan. Hal ini menunjukkan bahwa Retrun On Equity (ROE) dan memiliki hubungan positif terhadap nilai perusahaan.

Penelitian ini menerima hipotesis yang telah dikembangkan bahwa Retrun On Equity $(R O E)$ berpengaruh terhadap nilai perusahaan $(P B V)$. Hasil penelitian ini sejalan dengan penelitian yang dilakukan Jusriani dan Shidiq 
Nur (2013), dan penelitian yang dilakukan Mardiyati, Ahmad dan Ria Putri (2012) yang mengatakan bahwa variabel Retrun On Equity (ROE) mempunyai pengaruh terhadap nilai perusahaan $(P B V)$. Sehingga dapat disimpulkan bahwa semakin tinggi profitabilitas $(R O E)$ suatu perusahaan berarti semakin baik, karena meningkatkan harga saham yang berarti meningkatkan nilai perusahaan.

\section{Pengujian Deviden Payout Ratio (DPR) terhadap Nilai Perusahaan}

Pengujian hipotesis ketiga $\left(\mathrm{H}_{3}\right)$ dilakukan untuk menguji apakah DPR mempunyai pengaruh terhadap Nilai Perusahaan.

Penelitian ini menerima hipotesis yang telah dikembangkan bahwa Deviden Payou Ratio (DPR) berpengaruh terhadap nilai perusahaan $(P B V)$. Hasil penelitian ini sejalan dengan penelitian yang dilakukan Jusriani dan Shidiq Nur (2013) serta penelitian yang dilakukan oleh Septia, Ade Winda (2015) yang mengatakan bahwa variable Deviden Payout Ratio (DPR) mempunyai pengaruh terhadap nilai perusahaan $(P B V)$. Sehingga dapat disimpulkan bahwa jika dividen yang dibagikan perusahaan semakin besar, harga pasar saham perusahaan tersebut akan semakin tinggi yang berarti nilai perusahaan pun semakin tinggi dan sebaliknya.

\section{Pengujian Price Earning Ratio (PER) terhadap Nilai Perusahaan}

Pengujian hipotesis keempat $\left(\mathrm{H}_{4}\right)$ dilakukan untuk menguji apakah $P E R$ mempunyai pengaruh terhadap Nilai Perusahaan.

Penelitian ini menerima hipotesis yang telahdikembangkanbahwa PriceEarningRatio $(P E R)$ berpengaruh terhadap nilai perusahaan $(P B V)$. Hasil penelitian ini sejalan dengan penelitian yang dilakukan Septia, Ade Winda (2015) yang mengatakan bahwa variable Price Earning Ratio (PER) mempunyai pengaruh terhadap nilai perusahaan $(P B V)$. Sehingga dapat disimpulkan bahwa semakin besar PER suatu saham maka harga saham tersebut akan semakin tinggi terhadap pendapatan bersih per sahamnya yang berarti kesejahteraan pemegang saham semakin tinggi.

\section{KESIMPULAN}

Berdasarkan hasil pengujian maka dapat ditarik kesimpulan sebagai berikut:

1. Secara parsial, berdasarkan hasil uji t-hitung menunjukkan bahwa:

a. Variabel Firm Size (FS) tidak berpengaruh terhadap Nilai Perusahaan $(P B V)$ dan mempunyai hubungan positiff terhadap nilai Perusahaan $(P B V)$. Variabel Retrun On Equity (ROE) berpengaruh terhadap Nilai Perusahaan $(P B V)$ dan mempunyai hubungan positif terhadap nilai Perusahaan $(P B V)$. VariabelDeviden PayoutRatio(DPR) tidak berpengaruh terhadap Nilai Perusahaan $(P B V)$ dan mempunyai hubungan positif terhadap nilai Perusahaan $(P B V)$. Variabel Price Earning Ratio (PER) berpengaruh terhadap Nilai Perusahaan (PBV) dan mempunyai hubungan positif terhadap nilai Perusahaan (PBV).

2. Berdasarkan hasil uji F-hitung diperoleh kesimpulan bahwa secara bersama-sama (simultan) variabel bebas yang terdiri dari Retrun On Equity (ROE), Firm Size (FS), Deviden Payout Ratio (DPR), dan Price Earning Ratio (PER) berpengaruh terhadap Price Book to Value (PBV).

a. Hasil koefisien determinasi (Adjusted R Square) diperoleh nilai sebesar 0,695 atau kemampuan ROE, FS, DPR dan PER dalam menjelaskan $P B V$ sebesar $69,5 \%$. Sedangkan $\quad 30,5 \%$ dipengaruhi oleh faktor-faktor lain selain yang digunakan dalam penelitian ini.

\section{DAFTAR PUSTAKA}

Astuti dan Erma Setiawati. 2014. "Analisis Pengaruh Profitabilitas, Kebijakan Deviden, Kebijakan Hutang, dan Kepemilikan Manjerial Terhadap Nilai Perusahaan Manufaktur yang Terdaftar di Bursa Efek Indonesia Periode 2010 - 2012”. Seminar Nasional dan Call Paper. Hal 325 - 336.

Fahmi, Irham. 2015. Manajemen Investasi : 
Teori dan Soal Jawab. Edisi 2. Salemba Empat, Jakarta.

Ghozali, Imam. 2006. Aplikasi Analisis Multivariet Lanjutan dengan Program SPSS. Edisi 5. Semarang : Badan Penerbit UNDIP.

Gumanti, Tatang Ary. 2013. Kebijakan Deviden : Teori, Empiris, dan Implikasi. Edisi 4. UPP STIM YKPN, Yogyakarta.

Hanafi, Mamduh.M. 2004. Mnajemen Keuangan. Edisi 3. BPFE-Yogyakarta, Yogyakarta

Husnan, Suad. 1998. Manajemen Keuangan Teori dan Penerapan. Edisi 4. BPFEYogyakarta, Yogyakarta.

Jusriani dan Shidiq Nur. 2013. "Analisis Pengaruh Profitabilitas, Kebijakan Deviden, Kebijakan Hutang, dan Kepemilikan Manjerial Terhadap Nilai Perusahaan Manufaktur yang Terdaftar di Bursa Efek Indonesia Periode 2009 - 2011”. Diponegoro Journal of Accounting. Vol 2, No 2 : hal 1 - 10.

Jusriani, Ika Fanindya. 2013.“Analisis Profitabilitas, Kebijakan Deviden, , dan Kebijakan Hutang dan Kepemilikan Manajerial terhadap Nilai Perusahaan Manufaktur di BEI tahun 2009 - 2011". Skripsi. Semarang: Fakultas Ekonomi dan Bisnis, Universitas Diponegoro.

Mardiyati, Ahmad, dan Putri. 2012. "Pengaruh Kebijakan Deviden, Kebijakan Hutang, dan Profitabilitas Terhadap Nilai Perusahaan Manufaktur yang Terdaftar di Bursa Efek Indonesia Periode 2005 - 2010". Jurnal Riset Manajemen Sains Indonesia, FE Universitas Negeri Jakarta, Vol 3, No 1: hal 1-7.

Prapaska, Johan Ruth. 2012. “Analisis Tingkat Profitabilitas, Keputusan Investasi, Keputusan Pendanaan, dan Kebijakan
Deviden terhadap Nilai Perusahaan Manufaktur di BEI tahun 2009 - 2010". Skripsi. Semarang: Fakultas Ekonomi dan Bisnis, Universitas Diponegoro.

Raharjaputra, Hendra. S. 2009. Manajemen Keuangan dan Akuntansi untuk Eksekutif Perusahaan. Edisi 2. Salemba Empat, Jakarta.

Septia, Ade Winda. 2015."Pengaruh Profitabilitas, Keputusan Investasi, Keputusan Pendanaan dan Kebijakan Deviden terhadap Nilai Perusahaan Manufaktur di BEI". Skripsi. Yogyakarta: Fakultas Ekonomi, Universitas Negeri Yogyakarta.

Sudana, I Made. 2011. Manajemen Keuangan Perusahaan : Teori dan Praktek. Edisi 4. Erlangga, Jakarta.

Sumanti.J.C dan M.Mangantar. 2015. "Analisis Kepemilikan Manjerial, Kebijakan Hutang, dan Profitabilitas Terhadap Kebijakan Deviden dan Nilai Perusahaan Manufaktur yang Terdaftar di Bursa Efek Indonesia Periode 2008 - 2012. Jurnal EMBA. Vol 3, No 1: Hal $1141-1151$.

Tim Penyusun. 2014. Pedoman Penyusunan Skripsi. Surakarta : UMS.

Weston dan Thomas E. Copeland. 2010. Manjemen Keuangan Jilid 2. Edisi Revisi. Bina Rupa Aksara, Jakarta.

Winarno, Wing Wahyu. 2009 . Analisis Ekonometrika Dan Statistika Dengan Eviews. UPP STIMYKPN, Yogyakarta.

Yulita, Nola. 2014. Pengaruh Struktur Modal, Kebijakan Dividen, Dan Kepemilikan Manajerial Terhadap Nilai Perusahaan pada Perusahaan Manufaktur yang Terdaftar di Bursa Efek Indonesia Periode 2008 - 2012. Artikel Ilmiah. Universitas Negri Padang. 